\title{
Interaction of construction companies and Russian banks in residential mortgage lending
}

\author{
Tagirova E.R. \\ Institute of Management Economics and Finance \\ Kazan (Volga region) Federal University \\ Kazan, Russia \\ tagirovaer@mail.ru
}

\author{
Kopeykina K.S. \\ Institute of Management Economics and Finance \\ Kazan (Volga region) Federal University \\ Kazan, Russia.
}

\begin{abstract}
Specificity of construction companies requires borrowing capital. In particular, it is relevant for developers of residential properties. Despite the available demand of the population, the volume of construction has not shown sustainable growth in recent years. One of the reasons is the low availability of credit for this sector. Banks are cautious about this category of customers because of high risks. One of the ways to reduce credit risks is to consider the cooperation of construction companies and banks on mortgage programs. Thus, the source of repayment is formed and risks are reduced.

Also, an additional bank revenue is provided by the individuals' mortgage credit portfolio. The authors analyzed the relevant data for the period from 2010 to 2017 . The results of mortgage lending and the process of interaction between banks and construction companies are summarized. The authors indicated the level of overdue debts, which were issued to the construction industry, remained at a relatively high level. By comparison with other types of loans provided to individuals, it appears to be a low level of overdue debt on mortgage loans. The most important one is improving of an interaction between developers and credit institutions.
\end{abstract}

Keywords - mortgage lending, mortgage market, Russian banks, construction lending, risks of construction lending, interaction of construction companies and banks.

\section{INTRODUCTION}

House construction requires significant capital investment, so, as a rule, borrowed capital is used to finance it. At the same time, it is necessary to understand that access to the market for credit resources for developers is difficult, and just trusted and established companies can get bank trust [1].

\section{REVIEW AND ANALYSIS OF CONSTRUCTION LENDING}

Below are the conditions that must be taken into account by construction companies that build an object «from scratch». The conditions for obtaining loans by such companies are generally broader than for companies of other industries (for example, trade organizations):

a strong financial position;

investment of own capital;

complex procuring - the land plot under the real estate object, the pledge of property rights to the constructed areas;

availability of full amount of design and estimate documentation and all necessary permits.

From Table I, indicators of lending to construction organizations are displayed.

TABLE I. CREDITS FOR CONSTRUCTION

\begin{tabular}{|c|c|c|c|c|}
\hline \multirow[t]{2}{*}{ Reporting date } & \multicolumn{2}{|c|}{ Volumes of crediting } & \multirow{2}{*}{$\begin{array}{c}\text { share of loans granted to } \\
\text { construction companies in } \\
\text { total lending }\end{array}$} & \multirow{2}{*}{$\begin{array}{c}\text { rate of growth in } \\
\text { construction } \\
\text { lending }\end{array}$} \\
\hline & $\begin{array}{c}\text { construction, million } \\
\text { rubles. }\end{array}$ & total, million rubles. & & \\
\hline 01.01 .2010 & 851267 & 15759273 & $5,4 \%$ & - \\
\hline 01.01 .2012 & 1554452 & 25436234 & $4,2 \%$ & $52,7 \%$ \\
\hline 01.01 .2013 & 1815070 & 27531130 & $4,7 \%$ & $24,1 \%$ \\
\hline 01.01 .2014 & 2327741 & 31582836 & $5,3 \%$ & $39,6 \%$ \\
\hline 01.01 .2016 & 1269041 & 29995671 & $3,4 \%$ & $-44,9 \%$ \\
\hline 01.01 .2017 & 1405733 & 32395589 & $3,6 \%$ & $13,3 \%$ \\
\hline
\end{tabular}

Compiled by the authors on the basis of data from the Central Bank of the Russian Federation [2]

Despite the necessity of construction companies to finance and attract borrowed capital, their share in the loan portfolio of Russian banks is insignificant. In the period of seven years from 2010-2016, it was between $3.6 \%$ and $5.4 \%$ of the total volume of the national economy issued in all sectors. The rate of growth in construction lending is not 
positive and stable. The values of these indicators correspond to the dynamics of the commissioning of residential buildings upon completion of construction (Table II).

TABLE II. DYNAMICS OF COMMISSIONING OF RESIDENTIAL BUILDINGS, MILLION SQUARE METERS OF THE TOTAL AREA OF LIVING QUARTERS

\begin{tabular}{|l|l|l|l|}
\hline \multicolumn{1}{|c|}{ period } & \multicolumn{1}{|c|}{$\mathbf{2 0 1 5}$} & \multicolumn{1}{c|}{$\mathbf{2 0 1 6}$} \\
\hline 1 quarter & 18,6 & 15,6 & 13,1 \\
\hline 2 quarter & 16,1 & 15,9 & 14,9 \\
\hline 3 quarter & 17,7 & 18,0 & 18,4 \\
\hline 4 quarter & 32,9 & 30,7 & No data \\
\hline
\end{tabular}

Compiled by the authors on the basis of data from the Federal State Statistics Service of the Russian Federation

Thus, developers still need to attract borrowed capital. Increasing the volume of construction of residential buildings in the Russian Federation is impossible without additional funding from banks. Below you may consider the quality of loans granted to construction companies (Table III).

TABLE III. DATA ON THE LEVEL OF OVERDUE LOANS BY TYPE OF ECONOMIC ACTIVITY: CONSTRUCTION

\begin{tabular}{|c|c|c|c|}
\hline \multirow{2}{*}{ Reporting date } & \multicolumn{2}{|c|}{ Overdue debts of credits } \\
\cline { 2 - 4 } & Total, million rubles & $\begin{array}{c}\text { Construction, million } \\
\text { rubles } \\
\text { level of overdue debt construction in the total } \\
\text { amount of arrears for all types of economic } \\
\text { activity }\end{array}$ \\
\hline 01.01 .2010 & 601582 & 58749 & $9,8 \%$ \\
\hline 01.01 .2011 & 639486 & 66369 & $10,4 \%$ \\
\hline 01.01 .2012 & 733564 & 71900 & $9,8 \%$ \\
\hline 01.01 .2013 & 819856 & 68241 & $8,3 \%$ \\
\hline 01.01 .2014 & 861362 & 83438 & $9,7 \%$ \\
\hline 01.01 .2015 & 1128325 & 208028 & $18,4 \%$ \\
\hline 01.01 .2016 & 1676510 & 357341 & $21,3 \%$ \\
\hline 01.01 .2017 & 1749321 & 342039 & $19,6 \%$ \\
\hline
\end{tabular}

Compiled by the authors on the basis of data from the Central Bank of the Russian Federation [2]

In accordance with the data on the level of arrears in the construction industry, we can say that the loans in question have relatively higher risks. The level of overdue debt in this period ranges from $8.3 \%$ to $21.3 \%$ in the total amount of overdue loans for all types of economic activity. For comparison: "wholesale and retail trade" - from $22.4 \%$ to $39.7 \%$, "mining" - from $0.6 \%$ to $2.6 \%$.

The increased credit risks in this segment are due to the following reasons [3-5]:

- the complexity of the assessment and the high risks of lending to the project for the construction of the property;

- a risk of unfinished construction;

- uncertainty about the market reaction to this new facility and whether there will be demand for the area;

- the cost of construction may be higher than the market value of the object.

For reducing risks, construction loans are not issued at a time. The amount is given in installments in accordance with the limit of the credit line. Typically, the loan period is usually the same as the period that is needed to complete the construction.

At the same time, the credit analyst asks for confirmation of the full completion of the agreed amount of construction and installation works. To add more, the bank can lend in the provision of subcontractors' bills for the actual performed work. The bank together with the borrower (developer) should carefully analyze a set of factors, including the demand for this type of facilities, the capacity of the market, the ability of the builder to monitor the timing and cost estimates during construction, so as to complete the planned prices and, thus, terms of sale of habitation [6].

It should be noted that the source of repayment of the loan in question will be the proceeds from the sale of the constructed object. Because of that, the loan is repaid after completion of the construction.

Demand is an important factor that affects the result of the activity of construction companies. Demand for residential property can support and stimulate mortgage lending. Otherwise, there may be unclaimed areas. Thus, to ensure the sources of loan repayment and reduce the above identified risks, the developer (borrower) and the bank enter into an agreement on the possibility of providing mortgage loans to potential buyers for the acquisition of constructed facilities. As a result, the received mortgage loans and own funds of citizens are used to pay for housing, and developers are able to repay the previously obtained credit.

In a forth table you may consider the results of such cooperation (Table IV). 
TABLE IV. DATA ON MORTGAGE HOUSING LOANS

\begin{tabular}{|c|c|c|c|c|c|c|c|c|c|}
\hline \multirow[t]{2}{*}{ reporting date } & \multirow{2}{*}{$\begin{array}{c}\text { number of } \\
\text { operating } \\
\text { credit } \\
\text { institutions }\end{array}$} & \multirow[b]{2}{*}{$\begin{array}{c}\text { number of } \\
\text { credit } \\
\text { institutions } \\
\text { providing } \\
\text { mortgage } \\
\text { lending }\end{array}$} & \multirow[b]{2}{*}{$\begin{array}{c}\text { proportion } \\
\text { of credit } \\
\text { institutions } \\
\text { that } \\
\text { provide } \\
\text { mortgage } \\
\text { lending, } \\
\text { in \% }\end{array}$} & \multirow[b]{2}{*}{$\begin{array}{c}\text { increase in } \\
\text { the number } \\
\text { of credit } \\
\text { institutions } \\
\text { that } \\
\text { provide } \\
\text { mortgage } \\
\text { lending, } \\
\text { in } \%\end{array}$} & \multirow{2}{*}{$\begin{array}{l}\text { total debt by } \\
\text { mortgage } \\
\text { lending }\end{array}$} & \multirow[b]{2}{*}{$\begin{array}{c}\text { increase } \\
\text { in the } \\
\text { total } \\
\text { amount } \\
\text { of debt } \\
\text { on } \\
\text { mortgage } \\
\text { housing } \\
\text { loans, } \\
\text { in } \%\end{array}$} & \multicolumn{3}{|c|}{ including in \% of total debt } \\
\hline & & & & & & & $\begin{array}{l}\text { without } \\
\text { late } \\
\text { payments }\end{array}$ & $\begin{array}{c}\text { with } \\
\text { overdue } \\
\text { payments } \\
\text { over } 180 \\
\text { days }\end{array}$ & $\begin{array}{c}\text { with } \\
\text { overdue } \\
\text { payments } \\
\text { from } 1 \text { to } \\
180 \text { days }\end{array}$ \\
\hline 01.01 .2011 & 1013 & 631 & 62,3 & & 1129373 & - & 87,8 & 5,1 & 7,1 \\
\hline 01.01 .2012 & 978 & 658 & 67,3 & 4,3 & 1478982 & 31,0 & 94,1 & 3,7 & 2,3 \\
\hline 01.01 .2013 & 956 & 667 & 69,8 & 1,4 & 1997204 & 35,0 & 95,9 & 2,3 & 1,8 \\
\hline 01.01.2014 & 923 & 658 & 71,3 & $\begin{array}{c}- \\
1,3 \\
\end{array}$ & 2648859 & 32,6 & 96,1 & 1,8 & 2,2 \\
\hline 01.01 .2015 & 837 & 629 & 75,1 & $\begin{array}{c}- \\
4,4 \\
\end{array}$ & 3528379 & 33,2 & 95,5 & 1,8 & 2,7 \\
\hline 01.01 .2016 & 733 & 559 & 76,3 & $\begin{array}{c}- \\
11,1\end{array}$ & 3982237 & 12,9 & 94,7 & 2,5 & 2,9 \\
\hline 01.01 .2017 & 623 & 484 & 77,7 & $\begin{array}{c}- \\
13,4 \\
\end{array}$ & 4493155 & 12,8 & 95,6 & 2,3 & 2,1 \\
\hline
\end{tabular}

Compiled by the authors on the basis of data from the Central Bank of the Russian Federation [2]

As can be seen from Table IV, the share of banks which provide mortgage loans ranges from $62 \%$ to $78 \%$. This fact explains the negative aspects that accompany such transactions. These include a complex transaction structuring, low margin, limited "long" resources $[7,8]$. The issue of involvement of all credit institutions in mortgage lending can be viewed in different ways [9]. On the one hand, there is a growth zone and the necessity of innovative improvement of the mortgage market to increase the motivation of banks to provide loans. On the other hand, the models of organization of mortgage lending that have developed in the world practice do not imply $100 \%$ participation in them of all operating credit institutions. However, it is worth noting that credit institutions in the mortgage market are not limited to banks in the developed countries. There are credit unions, savings and loan organizations and others. In addition, the inflow of resources for mortgage lending comes additionally from a secondary stocks and bonds market. All these measures together allow solving the problems of shortage and high cost of funds.

It is worth paying attention to the trend of reducing the number of Russian banks that provide mortgage loans. As of beginning 2017 year their outflow amounted to $13 \%$. One of the main reasons is the annual reduction of operating credit institutions because of the revocation of licenses. These circumstances also affected the decline in the growth rate of mortgage lending from $35 \%$ to $13 \%$. For objectivity, it should be noted that social and economic factors affected the decline of the indicator in question.

A positive point is the low level of overdue debt, which amounted to 01.01 .2017 year $2.34 \%$ of the total volume of issued mortgage loans. This fact can support the interest of the bank in this type of lending [10].

\section{CONCLUSION}

In this way, we can conclude that the construction industry is not experiencing positive changes. This fact does not increase the chances for developers to reciprocate on the part of banks in attracting loans. One of the ways to solve the problem of availability of credit resources is joint mortgage programs. According to these programs, a bank offers facilities of the borrower-construction company for more attractive conditions for the population. Thus, there is a source of loan repayment, which helps a construction company to repay a debt to a bank. Also, credit risks are reduced and an additional revenue base of the bank in the form of a mortgage loan portfolio of individuals is provided.

It is also necessary to say that the housing construction program is being realized, and the production continuity in construction is achieved with the help of a mortgage loan. The construction of modern housing causes demand for many components, which stimulates the development of many sectors of the economy. For example, the production of building materials and structures, construction and road machinery, woodworking and the production of furniture, wallpaper, electrical equipment, metal products, etc. A new impetus is the development of transport infrastructure.

To draw a conclusion, mortgage programs have a positive impact on the activities of construction companies and the economy as a whole. However, just these programs are not able to significantly change the situation $[11,12]$. It is necessary to ensure the appropriate state support and regulation, work to increase the solvency of the population, develop and implement new technologies to attract funding to the mortgage market. 


\section{References}

[1] V.A. Savinova, D.Z. Vagapova, M.G. Sorokina, Methodological bases of definitions 'refinancing,' 'recrediting' and application practice in residential mortgage lending, International Journal of Economics and Financial Issues, Vol. 6, Issue 5, 2016, pp. 145-150.

[2] Bank of Russia. Official site of the Bank of Russia, 2017. Retrieved from: http://www.cbr.ru.

[3] D.V. Rylov, D.V. Shkurkin, A.A. Borisova, Estimation of the probability of default of corporate borrowers, Vol. 6, Issue 1S, 2016, pp. 63-67.

[4] O. Kurakova, N. Khomyak, Scenarios of Applying of Game Theory in Development Projects of Underground Construction, Procedia Engineering, Vol. 165, 2016, 15th International Scientific Conference 'Underground Urbanisation as a Prerequisite for Sustainable Development', ACUUS 2016; St.Petersbug; Russian Federation; 12 September 2016 to 15 September 2016, pp. 1221-1228.

[5] E.R. Tagirova, Stress testing in banking, Kazan economic vestnik, Vol. 27, Issue 1, 2017, pp. 42-47.

[6] N.A. Osadchaya, A.D. Murzin, E.E. Torgayan, Assessment of risks of investment and construction activities: Russian practice, Journal of Advanced Research in Law and Economics, Vol. 8, Issue 2, Spring 2017, pp. 529-544.

[7] O.V. Savchina, O.V. Savchina, A.L. Bobkov, A.Z. Sharashidze, On the state of the mortgage market in the Russian Federation in the conditions of global economic crisis, Journal of Applied Economic Sciences, Vol. 11, Issue 6, Fall 2016, pp. 1096-1103.

[8] A.I. Romanova, A.N. Afanasyeva, A.S. Mavlyautdinov, R.R. Mukharramova, T.A. Shindina, Socio-economic aspects of mortgage lending for housing construction in Tatarstan, International Journal of Economics and Financial Issues, Vol. 6, Issue 2, 2016, pp. 268-272.

[9] S.A. Gizatullin, E.R. Tagirova, Acquisition of commercial real estate: lending or leasing, International symposium on management, economics and finance: collection of scientific papers, Kazan, December 5-6, 2017, pp. 200-203.

[10] V.A. Savinova, D.Z. Vagapova, M.G. Sorokina, Methodological bases of definitions 'refinancing,' 'recrediting' and application practice in residential mortgage lending, International Journal of Economics and Financial Issues, Vol. 6, Issue 5, 2016. pp. 145-150.

[11] A.I. Romanova, G.M. Zagidullina, A.N. Afanasyeva, R.S. Hkairetdinova, Experience in the region to increase the availability of housing services, Mediterranean Journal of Social Sciences, Vol. 6, Issue 4S2, 1 July 2015, pp. 549-554.

[12] A.A. Tsyganov, A.D. Yazykov, Features of restructuring mortgage loans nominated in foreign currency, Studies on Russian Economic Development, Vol. 28, Issue 6, 1 November 2017, pp. 658-662. 
